\title{
Effectiveness of Neonatal Resuscitation Educational Intervention among undergraduate students: A systematic review
}

\author{
MISHAL LIAQAT ${ }^{1}$, MUHAMMAD HUSSAIN², MUHAMMAD AFZAL ${ }^{3}$ \\ ${ }^{1} \mathrm{MS}$ Nursing, ${ }^{2}$ Associate Professor, ${ }^{3}$ Principal \\ Lahore School of Nursing, The University of Lahore, Pakistan \\ Correspondence to: Ms. Mishal Liaqat, Cell: 0344-1481666, E-mail: mishee861@gmail.com
}

\begin{abstract}
Globally 2.7 million neonatal deaths are reported annually and among these $25 \%$ instigated by birth asphyxia. A substantial proportion of these deaths can be prevented through simple resuscitation efforts, in which education plays an integral role. Hence, it is important to assess if neonatal resuscitation educational interventions (NREI) integrating with varying instructional methods improve educational outcomes among undergraduates. We searched PubMed, Medline, Embase, Science Direct, Google Scholar, Cochrane. We selected randomized controlled trials (RCT), Non-randomized and cohort design had an education and comparing two educational interventions, describing at least one of our definite outcomes. A total of 13 manuscripts were relevant to the review, in which 7 papers comprises (level I), 5 (level II), and 2 (level III) were included. We found strong evidence on NREI for imparting knowledge and skills among undergraduates, nevertheless, little evidence exists for the long-term sustainability effect.

Keywords: Neonatal, Resuscitation, Students, Knowledge, Skills
\end{abstract}

\section{INTRODUCTION}

Globally 2.7 million neonatal deaths are reported annually ${ }^{1}$ and are estimated as $46 \%$ of the total deaths of under-five children. ${ }^{2}$ Nevertheless, the proportion of neonatal death is different from country to country. In developed countries, it is estimated as 3.7/1000 live birth whereas in developing countries the rate is about 10 times more in number. ${ }^{3}$ Although there are several contributing factors. However, birth asphyxia is the major cause accounts for $25 \%$ of neonatal deaths. ${ }^{1}$ While the poor quality of care is another significant factor associated with approximately two-third of neonatal deaths worldwide. ${ }^{4}$ Hence, both of these factors can be controlled through trained birth attendants in which education plays an integral role.

The first educational program in neonatal resuscitation was introduced in 1987 by the American Academy of Pediatrics Neonatal Resuscitation Program (NRP) in the United States. ${ }^{5}$ Since its inception in the neonatal resuscitation program, we are still in the struggle to find out the best strategies to disseminate NRP knowledge, training, and guidelines to health providers that promise the best outcome. ${ }^{6}$ While the educational efficacy is inclined by the instructional design including but not limited to skill learning, deliberate practice, mentoring, feedback, evaluation, and other advanced educational approaches. Consequently, enhancing instructional design in different innovative settings can improve educational outcomes. $^{7}$

Hence, little published data on this phenomenon is available regarding undergraduate students. That determines the best way to educate them in performing the skills that urgently require an infrequent needed such as neonatal resuscitation. Therefore, this systemic review is to synthesize the evidence that addresses the efficacy of NREI in emerging knowledge and skill among undergraduate students. Additionally, this review helps in classifying the active approaches in the education of undergraduates that best meet to achieve their educational goals.

\section{MATERIALS AND METHODS}

A total of 2,220 articles were found initially and 718 papers were duplicated. Subsequently, screening for title and abstract 70 studies had to meet our inclusion criteria. Ultimately, 13 articles were selected after full-text review analysis. We searched the databases of PubMed, Medline, Cochrane, Science Direct, Embase, Google Scholar for relevant articles and follow PRISMA guidelines for reporting systemic review. All published literature with the independence of the timeline and written in English were included. Empirical studies assessing the effect of an educational intervention in neonatal resuscitation among undergraduates including medical, nursing and midwifery students were eligible. The randomized controlled trials (RCTs), nonrandomized, retrospective, and prospective cohort design, with or without control reported at least one of our outcomes' knowledge and skill.

The search strategy was (newborn OR neonatal) AND resuscitation) OR (newborn OR neonatal Resuscitation) AND (Teaching OR education OR training OR Intervention) OR (skills OR knowledge) AND (undergraduate students OR Nursing students OR medical students OR Midwifery students) OR (newborn OR neonatal resuscitation) AND (Teaching OR education OR training OR Intervention) AND (skills OR knowledge) AND (effect OR Impact) OR (newborn OR neonatal Resuscitation) AND (Teaching OR education OR training OR Intervention) AND (skills OR knowledge) AND(effect OR Impact) AND (undergraduate students OR Nursing students OR medical students OR Midwifery students).

Two reviewers independently extracted and manage all data any confusion and discrepancy, were resolved through mutual discussion, and contact the relevant study authors for further clearance. Further, disagreements were 
resolved from a third independent reviewer (MA) who independently cross-check all data.

\section{RESULTS}

The study participants were undergraduate medical, nursing, and midwifery students. The sample size varied from 10 to 1214 study participants. A total of 7 studies were Randomize control trials (level I), 4 quasi-experimental (level 2), 1 retrospective cohort, and 1 was prospective cohort study (level 3) according to ILCOR level of evidence guideline. All the studies were evaluating the NREI on changes in knowledge and skill of undergraduate students as a study outcome. The knowledge was tested after intervention through multiple choice questions (MCQs) or written tests while the skill was tested through a skill checklist or objective structured clinical examination (OSCE) [Table 1].

Effect of NREI based on simulation: Since its inception simulation is the chief component of neonatal resuscitation. ${ }^{8}$ Lai et $\mathrm{al}^{9}$ investigating the efficacy of a brief simulation-based workshop on updating knowledge in neonatal resuscitation. The 56 final-year medical students were retrospectively analyzed for intervention. The pretest knowledge score was $11.7 \pm 2.5$ and the post-test was $16.2 \pm 1.9$ had $P \leq 0.001$. Promising was the fact that students significantly improve knowledge in postintervention.

Curran et $\mathrm{al}^{10}$ compare the efficacy of high fidelity versus low fidelity simulation among 66 third-year medical students in Canada. The students were randomly assigned to high and low fidelity groups. The study found both approaches were equally effective $(p=0.45)$ with high fidelity means the score was 10.3 , and low fidelity means the score was 10.0. A further study to evaluate the effect of high versus low fidelity simulation was conducted by Nimbalkar et al ${ }^{11}$ among 101 final-year medical students in India. The theoretical content was the same for both groups. Following lectures, students were divided into low and high fidelity through randomization. Overall, knowledge and skill were improved with insignificant difference. As the post-test knowledge score of the low fidelity group and high fidelity were $33.90 \pm 3.28,35.16 \pm 2.67$ with $p=0.39$ and mean skill score were $29.67 \pm 5.57,31.46 \pm 6.14$ with $p=0.92$ respectively.

Further, Abusaad and Ebrahem ${ }^{12}$ studied the simulation-based education (SBE) versus the traditional method among 100 pediatric nursing students in Egypt. The SBE group practice skill through simulation scenarios on high fidelity simulator whereas, the traditional group practice on the static manikin. Overall, both SBE and the traditional method improved knowledge and skill. However, the mean final score of knowledge in the SBE group was $17.70 \pm 2.82$ significantly higher than the traditional method of $20.08 \pm 1.71$. Similarly, the mean final score of skill in the SBE group was $37.06 \pm 5.82$ significantly higher $(P<0.005)$ than the traditional method $22.92 \pm 8.00$.

In another study, Saeidi and Gholami $^{13}$ were assessing the proficiency of simulation-based education versus the traditional method in Iran. An equal number of students were divided into Simulation-based education (SBE) group and a traditional group. The SBE group establishes skills on a moulage while the other learns through the traditional method. Overall, both interventions improve knowledge. Yet, the post-test score of SBE $19.31 \pm 0.5$ was significantly higher than the traditional group $14.25 \pm 1.35$ with $p<0.001$ was found.

Finally, the role of simulation as a booster strategy was observed by Curran et al $^{14}$ who compared 2 booster strategies of a computer-assisted high-fidelity simulator (ANAKIN) with instructional video after an NRP training. The 60 (3rd -year) medical students were randomly assigned to booster strategies either the ANAKIN system or an NRP instructional video at 4-month after the NRP. Both strategies were found ineffective in improving knowledge and skill as a booster with the mean knowledge score for the experimental group was $21.43 \pm 2.11$ and the control was $20 \pm 2.53$ without any significant difference.

NREI based on Computer-assisted Teaching: Kumar and Ptidar $^{15}$ investigated the expediency of computerassisted teaching on knowledge acquisition in neonatal resuscitation. The 60 ( $3^{\text {rd }}$ year) nursing students and assign equally to the experimental and control group. The experimental group was provided a 45minute computerassisted teaching in neonatal resuscitation. However, the control group did not receive any education. The study found computer-assisted teaching was effective as the post-test mean knowledge score for the experiment group was $21.76 \pm 1.6$ significantly higher than the control group $11.33 \pm 1.1$.

NREI based on Pediatric Basic life support (PBLS): Lopez-Herce et al $^{16}$ compare the efficacy of two courses Pediatric Basic Life Support (PBLS) with Pediatric Immediate Life Support (PILS). The study retrospectively analyzed the results of 1214 medical students enrolled in the PBLS and PILS courses during their final year. The pretest knowledge means score for PBLS was 11.4 \pm 2.8 compared to the post-test $19.4 \pm 1.8$ had $\mathrm{P}<0.0001$. The pretest mean knowledge score of PILS was $17.3 \pm 3.7$ compare to post-test $29.1 \pm 1.3$ had $P<0.0001$. The skill test of PBLS had a pass rate of $97 \%$ compared to the PILS pass rate of $99 \%$. Both interventions were found equally effective regarding the acquisition of knowledge and skill.

NREI based on Video assisted teaching: Elarousy et $\mathrm{al}^{17}$ evaluating the efficiency of E-learning in enhancing knowledge, skill in neonatal resuscitation among undergraduate nursing students. The students were randomly assigned to the experimental and control group and taught through demonstration and redemonstration. The experimental group additionally received a video on neonatal resuscitation in the second week. The total knowledge score for the control and experimental group was $4.12 \pm 0.93,4.67 \pm 0.82$ respectively $(P=0.067)$. While, the final mean skill score for the control and experimental group was $18.96 \pm 1.90,19.13 \pm 1.73$ respectively $(P=0.775)$. The study reported insignificant differences among both groups.

A further study by Pinar et al ${ }^{18}$ was investigating the effectiveness of video-assisted simulation education among nursing students in Turkey. The students were selected randomly and further randomly allocated in the intervention and control group. Following the lecture, the intervention group received a video-based simulation education. The post-test mean score for knowledge for intervention and control groups was $13.48 \pm 1.44$ and $12.00 \pm 1.22$ 
respectively with $p<0.001$. Similarly, the post-test mean skill for the intervention group was $18.43 \pm 2.46$ significantly higher than the control group $10.09 \pm 3.17$ with $\mathrm{P}<0.05$. The study reported that the addition of video-based simulation with theory potentiates the effect significantly.

Another study by Stephan et $\mathrm{al}^{19}$ compared the usefulness of video teaching versus peer teaching in pediatric basic life support (PBLS). The $88\left(4^{\text {th }}\right.$ year) medical students were randomly assigned to video teaching and peer teaching groups equally. A 12-minute video teaching and peer teaching session were conducted separately for both groups. The peer teaching group accomplish a significantly higher score was $19.0 \pm 0.4$ as compared to video teaching $17.3 \pm 0.5$ had $P=0.008$.

NREI based on other methods: Kim and $\mathrm{Ahn}^{20}$ compare the impact of 5 step method of George and Doto versus 2 steps traditional method in the learning of pediatric CPR. The post-intervention mean knowledge score for control was $13.94 \pm 1.85$ and experimental $14.46 \pm 1.62$ with an insignificant difference $(p=0.248)$. Yet, the performance ability for control was $7.03 \pm 1.33$ and experimental $8.71 \pm 1.48$ had $p<0.001$. The 5 -step method suggestively enhances performance as compare to the traditional method.

Nourkami-Tutdibi et $\mathrm{al}^{21}$ compared the effectiveness of modifying Peyton's approach versus traditional Peyton's four-step approach (P4S) on augmenting knowledge and skill in neonatal resuscitation. The 94 medical students of $4^{\text {th }}$ and $5^{\text {th }}$ year randomly assigned to control and trial groups. The post means knowledge for control and trial was $14.0 \pm 3.3,14.8 \pm 3.2$ respectively with $p<0.187$. Similarly, the final skill score for control and trial was 27.3 \pm 2.6 , $27.6 \pm 2.3$ with $p<0.527$. Neither the traditional nor the modified Peyton approach had any significant difference in cognitive and technical skills.

Retention of cognitive and Technical skill: Maintenance of knowledge and skill was observed by 7 studies range from 1 month to 10 months after the intervention. All the studies conducted by Lai et $\mathrm{al}^{9}$, Curran et $\mathrm{al}^{10}$, Nimbalkar et $\mathrm{al}^{11}$, Abusaad and Ebrahem ${ }^{12}$, Kim and $\mathrm{Ahn}^{20}$ and Nourkami-Tutdibi et $\mathrm{al}^{21}$ reported a decline in skill and knowledge after the interval. Only one study conducted by Stephan et al $^{19}$ reported an increase in skill at 10weeeks of interval. The post knowledge and skill difference with follow-up were presented in Table 2.

\section{DISCUSSION}

Globally, educational training in neonatal resuscitation is well established and acknowledged by the students and medical personnel. However, little published literature defined, measured, and reported on teaching strategy, length of the program as well as the outcome on the cognitive and psychomotor level among undergraduates. In a previous review of resuscitation training by Meaney et $\mathrm{al}^{22}$ also established the concept that the baseline knowledge and skill vary between and within disciplines and become challenging with a change in location. Thus, it is highly imperative to define each system, student type, educational tactics, baseline measurement, and its outcome could be established.

This review established 13 papers grounded on NREI geared toward enhancing knowledge and skill among undergraduate students. Six of the studies utilized simulation in which one study by Lai et $\mathrm{al}^{9}$ established simulation effective in improved knowledge. While three studies Curran et $\mathrm{al}^{10}$, Nimbalkar et $\mathrm{al}^{11}$ and Curran et $\mathrm{al}^{14}$ compared the efficiency comprising high versus low fidelity. All studies (level I) are in the same line that high fidelity and low fidelity were equally effective in enhancing knowledge and skill among undergraduates. These results were contrary to Abusaad and Ebrahem ${ }^{12}$ \& Saeidi and Gholami $^{13}$ (level II) who reported high fidelity was significantly more effective as compared to the traditional static manikin. While Kumar and Ptidar ${ }^{15}$ (level II) reported computer-assisted teaching was significantly effective as compare to control in upgrading knowledge.

Further, two studies of (level 1) were conducted by Elarousy et $\mathrm{al}^{17}$ \& Pinar et $\mathrm{al}^{18}$ on the effectiveness of video learning. Both studies' results were in accordance that the addition of video-based simulation with theory potentiates the effect significantly. While, another study by Stephan et $\mathrm{al}^{19}$ reported peer learning is a more effective approach to enhancing skill as compared to videos. Retention of knowledge and skill further studied by 7 articles range from 1 month to 10 months after the intervention. All papers reported decline occur at cognitive and psychomotor level irrespective of the type of strategy and duration of the program. Based on the results of our systemic review, NREI proved effective in enhancing knowledge and skill with added innovative instructional design based on simulation, computer-assisted, e-learning, and peer learning. Our study accentuated the need for further studies to investigate the optimal frequency of booster strategies for knowledge and skill maintenance though NREI upgraded performance primarily. Yet, cognitive and technical skills decline with time.

\begin{tabular}{|c|c|c|c|c|c|c|}
\hline Author & Design (Level) & $\begin{array}{l}\text { Participants } \\
\text { (sample Size) }\end{array}$ & Comparison & $\begin{array}{l}\text { Intervention } \\
\text { +Length }\end{array}$ & Evaluation & $\begin{array}{l}\text { Outcomes } \\
\text { (p-value) }\end{array}$ \\
\hline Curran et $\mathrm{al}^{14}$ & $\mathrm{RCT}(\mathrm{I})$ & $\begin{array}{l}\text { 3rd-year medical } \\
\text { students }(n=60)\end{array}$ & $\begin{array}{l}\text { Pretest-posttest } \\
\text { with CG }\end{array}$ & $\begin{array}{l}\text { NRP booster via computer } \\
\text { simulator }(n=30) \text { vs video }(n=30)+ \\
4 \text { months }\end{array}$ & $\begin{array}{l}\text { NRP checklist (skill), } \\
\text { MCQ (Knowledge) }\end{array}$ & $\begin{array}{l}\text { Insignificant results } \\
(p=.927 \text { for } \\
\text { Knowledge, } 1 p \\
=0.841 \text { for skill) }\end{array}$ \\
\hline Curran et $\mathrm{al}^{10}$ & $\mathrm{RCT}(\mathrm{I})$ & $\begin{array}{l}\text { 3rd year medical } \\
\text { students }(n=66)\end{array}$ & $\begin{array}{l}\text { posttest- only with } \\
\text { CG }\end{array}$ & $\begin{array}{l}\text { NRP learning through high }(n=31) \\
\text { vs low fidelity simulator }(n=35)+2 \\
\text { days }\end{array}$ & $\begin{array}{l}\text { Mega code } \\
\text { Assessment (Skill) }\end{array}$ & $\begin{array}{l}\text { Insignificant results } \\
(p=0.45)\end{array}$ \\
\hline Kim \& Ahn ${ }^{20}$ & $\begin{array}{l}\text { Quasi- } \\
\text { experimental (II) }\end{array}$ & $\begin{array}{l}\text { Nursing students } \\
(n=61)\end{array}$ & $\begin{array}{l}\text { pretest-posttest } \\
\text { with CG }\end{array}$ & $\begin{array}{l}\text { CPR 5-step method }(n=28) \text { vs } \\
\text { traditional }(n=33) \text { N. R }\end{array}$ & $\begin{array}{l}\text { MCQ } \\
\text { (Knowledge)Skill } \\
\text { checklist (skill) }\end{array}$ & $\begin{array}{l}\text { Significant results } \\
(\mathrm{P}=.248 \text { for } \\
\text { knowledge, } \\
\mathrm{P}<0.001 \text { for skill })\end{array}$ \\
\hline $\begin{array}{l}\text { Saeidi \& } \\
\text { Gholami }^{13}\end{array}$ & $\begin{array}{l}\text { Quasi- } \\
\text { experimental (II) }\end{array}$ & $\begin{array}{l}2^{\text {nd }} \text { year nursing } \\
\text { students }(n=80)\end{array}$ & $\begin{array}{l}\text { pretest-posttest } \\
\text { with CG }\end{array}$ & $\begin{array}{l}\text { simulation-based }(n=40)) \text { VS } \\
\text { traditional method }(n=40), 4 \text { weeks }\end{array}$ & $\begin{array}{l}\text { Knowledge } \\
\text { questionnaire }\end{array}$ & $\begin{array}{l}\text { Significant results } \\
(p<0.001)\end{array}$ \\
\hline
\end{tabular}




\begin{tabular}{|c|c|c|c|c|c|c|}
\hline $\begin{array}{l}\text { Nourkami-Tutdibi } \\
\text { et } \mathrm{al}^{21}\end{array}$ & Prospective RCT & $\begin{array}{l}\text { 4th to } 5 \text { th-year } \\
\text { medical students } \\
(n=123)\end{array}$ & posttest- with CG & $\begin{array}{l}\text { Modified Peyton's four-step } \\
\text { approach }(n=52) \text { VS traditional } \\
\text { Peyton's four-step ( } n=42),(12 \\
\text { weeks) }\end{array}$ & $\begin{array}{l}\text { MCQ (Knowledge), } \\
\text { Mega code (skill) }\end{array}$ & $\begin{array}{l}\text { Insignificant results } \\
(\mathrm{P}<0.187 \text { for } \\
\text { knowledge, } \\
\mathrm{P}<0.527 \text { for skill })\end{array}$ \\
\hline Nimbalkar et al ${ }^{11}$ & $\mathrm{RCT}(\mathrm{I})$ & $\begin{array}{l}5^{\text {th }} \text {-year medical } \\
\text { students }(n=101)\end{array}$ & $\begin{array}{l}\text { pretest-posttest } \\
\text { with CG }\end{array}$ & $\begin{array}{l}\text { High fidelity simulation }(n=50) \text { VS } \\
\text { low fidelity }(n=51), 3 \text { days }\end{array}$ & $\begin{array}{l}\text { MCQ (Knowledge), } \\
\text { Mega code (skill) }\end{array}$ & $\begin{array}{l}\text { Insignificant results } \\
(p=0.92 \text { for skill } \\
p=0.39 \text { for } \\
\text { knowledge })\end{array}$ \\
\hline Stephan et al ${ }^{19}$ & $\begin{array}{l}\text { Prospective RCT } \\
\text { (I) }\end{array}$ & $\begin{array}{l}4^{\text {th }} \text {-year medical } \\
\text { students }(n=88)\end{array}$ & posttest- with CG & $\begin{array}{l}\text { Peer teaching }(n=44) \text { VS Video- } \\
\text { based pediatric BLS }(n=44), 1 \\
\text { week }\end{array}$ & OSCE for skill & $\begin{array}{l}\text { Significant results } \\
(p=0.008)\end{array}$ \\
\hline Lai et $\mathrm{al}^{9}$ & $\begin{array}{l}\text { Retrospective } \\
\text { cohort study (III) }\end{array}$ & $\begin{array}{l}5^{\text {th }} \text {-year medical } \\
\text { students }(n=56)\end{array}$ & $\begin{array}{l}\text { Pre- and post- } \\
\text { assessment }\end{array}$ & $\begin{array}{l}\text { Neonatal Resuscitation Provider } \\
\text { (NRP) program, } 6 \text { weeks }\end{array}$ & MCQ (Knowledge) & $\begin{array}{l}\text { Significant results } \\
(p \leq 0.001)\end{array}$ \\
\hline $\begin{array}{l}\text { Lopez-Herce et } \\
\mathrm{al}^{16}\end{array}$ & $\begin{array}{l}\text { Prospective } \\
\text { cohort (III) }\end{array}$ & $\begin{array}{l}5^{\text {th }} \text { year medical } \\
\text { students }(n=1214)\end{array}$ & $\begin{array}{l}\text { pretest-posttest } \\
\text { with Control } \\
\text { Group }\end{array}$ & $\begin{array}{l}\text { pediatric basic life support }(n=738) \\
\text { VS pediatric immediate life } \\
\text { support }(n=476), 3 \text {-days }\end{array}$ & $\begin{array}{l}\text { MCQ (Knowledge), } \\
\text { criteria for skill }\end{array}$ & $\begin{array}{l}\text { Insignificant results } \\
(p<0.0001)\end{array}$ \\
\hline $\begin{array}{l}\text { Abusaad \& } \\
\text { Ebrahem }^{12}\end{array}$ & $\begin{array}{l}\text { Quasi- } \\
\text { experimental (II) }\end{array}$ & $\begin{array}{l}\text { Nursing students } \\
(n=100)\end{array}$ & $\begin{array}{l}\text { pretest-posttest } \\
\text { with CG }\end{array}$ & $\begin{array}{l}\text { Simulated based }(n=50) \text { versus } \\
\text { traditional }(n=50),(N . R)\end{array}$ & $\begin{array}{l}\text { Knowledge } \\
\text { questionnaire } \\
\text { (knowledge), } \\
\text { checklist (skill) }\end{array}$ & $\begin{array}{l}\text { Significant results } \\
(P<0.005)\end{array}$ \\
\hline Kumar \& Ptidar ${ }^{15}$ & $\begin{array}{l}\text { Quasi- } \\
\text { experimental (II) }\end{array}$ & $\begin{array}{l}3^{\text {rd }} \text { year nursing } \\
\text { students }(n=60)\end{array}$ & $\begin{array}{l}\text { pretest-posttest } \\
\text { with CG }\end{array}$ & $\begin{array}{l}\text { Computer Assisted Instructions } \\
(n=30) \text { with control group }(n=30) \text {, } \\
45 \text { min }\end{array}$ & $\begin{array}{l}\text { Knowledge } \\
\text { Questionnaire }\end{array}$ & $\begin{array}{l}\text { Significant } \\
\text { difference } \\
(p<0.005)\end{array}$ \\
\hline Pinar et $a^{18}$ & $\mathrm{RCT}(\mathrm{I})$ & $\begin{array}{l}\text { Nursing students } \\
(\mathrm{n}=46)\end{array}$ & $\begin{array}{l}\text { pretest-post test } \\
\text { with CG }\end{array}$ & $\begin{array}{l}\text { video-based simulation }(n=23) \text { Vs } \\
\text { lecture }(n=23), 3 \text { hours }\end{array}$ & $\begin{array}{l}\text { Knowledge Form, } \\
\text { OSCE for skill }\end{array}$ & $\begin{array}{l}\text { Significant results } \\
(p<0.005)\end{array}$ \\
\hline Elarousy et $\mathrm{al}^{17}$ & $\mathrm{RCT}(\mathrm{I})$ & $\begin{array}{l}\text { Nursing students } \\
(n=40)\end{array}$ & $\begin{array}{l}\text { posttest-only with } \\
\text { CG }\end{array}$ & $\begin{array}{l}\text { Video-based E-learning }(n=15) \text { VS } \\
\text { lecture }(n=25), 2 \text { weeks }\end{array}$ & $\begin{array}{l}\text { MCQ (knowledge), } \\
\text { Neonatal } \\
\text { resuscitation } \\
\text { checklist (skill) }\end{array}$ & $\begin{array}{l}\text { Insignificant } \\
\text { difference } \\
\text { ( } p=0.067 \text { for } \\
\text { knowledge, } \\
p=0.775 \text { for skill) }\end{array}$ \\
\hline
\end{tabular}

NR (Not Reported), CG (control Group), MCQ (Multiple-choice question), OSCE (Objective Structured Clinical Examination)

Table 2: The post knowledge and skill difference with follow-up measures

\begin{tabular}{|c|c|c|c|c|}
\hline Author & Post knowledge & Retention Knowledge & Post skill & Retention skill \\
\hline Curran et $\mathrm{al}^{10}$ & $\begin{array}{l}\text { Exp } 21.43 \pm 2.11 \\
\text { Cont. } 20 \pm 2.53\end{array}$ & 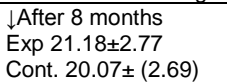 & $\begin{array}{l}\text { Exp } 232.76 \pm 14.72 \\
\text { Cont.227.21 } 14.18\end{array}$ & $\begin{array}{l}\downarrow \text { After 8 months } \\
\text { Exp } 210.98 \pm 22.5 \\
\text { Cont. } 199.89 \pm 13.81\end{array}$ \\
\hline Kim \& Ahn ${ }^{20}$ & $\begin{array}{l}\text { Exp } 14.46 \pm 1.62 \\
\text { Cont. } 13.94 \pm 1.85\end{array}$ & $\begin{array}{l}\text { After } 6 \text { months } \\
\text { Exp } 12.57 \pm 1.68 \\
\text { Cont. } 11.79 \pm 2.47\end{array}$ & $\begin{array}{l}\text { Exp } 8.71 \pm 1.48 \\
\text { Cont. } 7.03 \pm 1.33\end{array}$ & $\begin{array}{l}\downarrow \text { After } 6 \text { months } \\
\text { Exp } 4.96 \pm 1.79 \\
\text { Cont. } 3.85 \pm 1.90\end{array}$ \\
\hline Nourkami-Tutdibi et al ${ }^{21}$ & - & - & $\begin{array}{l}\text { Exp } 27.6 \pm 2.3 \\
\text { Cont. } 27.3 \pm 2.6\end{array}$ & $\begin{array}{l}\downarrow \text { After } 6 \text { months } \\
\text { Exp } 25.1 \pm 4.3 \\
\text { Cont. } 25.6 \pm 4.3\end{array}$ \\
\hline Nimbalkar et al ${ }^{11}$ & $\begin{array}{l}\text { Exp } 35.16 \pm 2.67 \\
\text { Cont. } 33.90 \pm 3.28\end{array}$ & $\begin{array}{l}\text { After } 3 \text { months } \\
\text { Exp } 32.91 \pm 3.57 \\
\text { Cont. } 32.43 \pm 3.33 \\
\end{array}$ & $\begin{array}{l}\text { Exp } 31.46 \pm 6.14 \\
\text { Cont. } 29.67 \pm 5.57\end{array}$ & $\begin{array}{l}\downarrow \text { After } 3 \text { months } \\
\text { Exp } 29.25 \pm 6.17 \\
\text { Cont. } 30.15 \pm 5.56 \\
\end{array}$ \\
\hline Stephan et al ${ }^{19}$ & - & - & $\begin{array}{l}\text { Exp 19.0 } \pm 0.4 \\
\text { Cont. } 17.3 \pm 0.5\end{array}$ & $\begin{array}{l}\uparrow \text { After } 10 \text { weeks } \\
\text { Exp } 20.6 \pm 0.4 \\
\text { Cont. } 18.6 \pm 0.5\end{array}$ \\
\hline Lai et $\mathrm{al}^{9}$ & $16.2 \pm 1.9$ & $\begin{array}{l}\downarrow \text { After } 1 \text { month } \\
13.6 \pm 2.3\end{array}$ & - & - \\
\hline Abusaad \& Ebrahem ${ }^{12}$ & $\begin{array}{l}\text { Exp } 20.08 \pm 1.71 \\
\text { Cont. } 17.70 \pm 2.82\end{array}$ & $\begin{array}{l}\downarrow \text { After } 3 \text { months } \\
\text { Exp } 19.94 \pm 1.80 \\
\text { Cont. } 17.38 \pm 2.62\end{array}$ & $\begin{array}{l}\text { Exp } 37.06 \pm 5.82 \\
\text { Cont. } 22.92 \pm 8.00\end{array}$ & $\begin{array}{l}\downarrow \text { After } 3 \text { months } \\
\text { Exp } 36.74 \pm 5.56 \\
\text { Cont. } 21.84 \pm 7.09\end{array}$ \\
\hline
\end{tabular}

Exp (Experiment), Cont. (Control), $\downarrow$ (decrease) $\uparrow$ (increase)

\section{CONCLUSION}

This review shows that the execution of NREI expands cognitive and psychomotor skills. Particularly, the alliance of simulation and self-reliant learning integrating with computers, and videos has the potential to improve learning as compared to traditional methods. Yet, evidence regarding sustaining effect is limited. Further research is looked for to augment the programs with additional good quality, multicenter randomized controlled studies investigating the NREI with mixed instructional designs for retaining effect is warranted. Moreover, the best combination of settings, strategy, type, and frequency of booster strategies is inevitable to improve retention.

\section{REFERENCES}

1. Mendhi MM, Cartmell KB, Newman SD, Premji S, Pope C. Review of educational interventions to increase traditional birth attendants' neonatal resuscitation self-efficacy. Women and birth. Aust Coll Midwives Inc J 2019;32(1):16-27.
2. Organization WH. Primary health care systems (Primasys): Case study from Rwanda. Geneva; 2017.

3. Nyiringango G. Assessing Changes in Knowledge about and Self-efficacy for Neonatal Resuscitation Among Rwandan Nurses and Midwives after a Mentorship Process [Electronic Thesis and Dissertation Repository]: The University of Western Ontario; 2019.

4. Kruk ME, Gage AD, Arsenault C, Jordan K, Leslie $\mathrm{HH}$, Roder-DeWan S, et al. High-quality health systems in the Sustainable Development Goals era: time for a revolution. Lancet Glob Health 2018;6(11):e1196-e252.

5. Kamath-Rayne BD, Berkelhamer SK, Ashish K, Ersdal HL, Niermeyer $S$. Neonatal resuscitation in global health settings: an examination of the past to prepare for the future. Pediatr Res 2017;82(2):194-200.

6. Kak L, Johnson J, McPherson R, Keenan W, Schoen E. Helping babies breathe global development alliance and the power of partnerships. Pediatrics 2020;146(2).

7. Cheng A, Nadkarni VM, Mancini MB, Hunt EA, Sinz EH, Merchant RM, et al. Resuscitation education science: educational strategies to improve outcomes from cardiac arrest: a scientific statement from the American Heart Association. Circulation 2018;138(6):e82-e122. 
8. Halamek LP. Simulation and debriefing in neonatology 2016: Mission incomplete. Semin Perinatol 2016;40(7):489-93.

9. Lai NM, Ngim CF, Fullerton PD. Teaching medical students neonatal resuscitation: knowledge gained and retained from a brief simulation-based training workshop. Educ Health 2012;25(2):105.

10. Curran V, Fleet L, White S, Bessell C, Deshpandey A, Drover A, et al. A randomized controlled study of manikin simulator fidelity on neonatal resuscitation program learning outcomes. Adv Health Sci Educ Theory Pract 2015;20(1):205-18.

11. Nimbalkar A, Patel D, Kungwani A, Phatak A, Vasa R, Nimbalkar S. Randomized control trial of high fidelity vs low fidelity simulation for training undergraduate students in neonatal resuscitation. BMC Res Notes 2015;8(1):1-7.

12. Abusaad FES, Ebrahem GGS. The changes on knowledge, confidence and skills accuracy of nursing students at a simulated based setting versus traditional during neonatal resuscitation. Int J Nurs Diabetics 2015;5(4):11-21.

13. Saeidi R, Gholami M. Comparison of effect of simulationbased neonatal resuscitation education and traditional education on knowledge of nursing students. Iran J Neonatol 2017;8(2):50-2.

14. Curran V, Aziz K, O'Young S, Bessell C. Evaluation of the effect of a computerized training simulator (ANAKIN) on the retention of neonatal resuscitation skills. Teach Learn Med 2004;16(2):157-64.

15. Kumar N, Ptidar D. Assess the effectiveness of computer assisted teaching (CAT) on knowledge gain about neonatal resuscitation among B. Sc. nursing 3rd year students of selected Nursing Colleges at Bhopal, Madhya Pradesh, India. Trends Nurs Administration Educ 2019;8(1):7-12.
16. López-Herce J, Carrillo Á, Martínez Ó, Morito AM, Pérez S, López $J$, et al. Basic and immediate paediatric cardiopulmonary resuscitation training in medical students. Educ Medica 2019;20(3):155-61.

17. Elarousy W, Abdulshakoor E, Bafail R, Shebaili M. The effectiveness of e-learning in enhancing neonatal resuscitation skills, knowledge and confidence of undergraduate nursing students. Int $J$ Nurs Clin Pract 2014;1:2-7.

18. Pinar G, Akalin A, Abay $\mathrm{H}$. The effect of video based simulation training on neonatal examination competency among Turkish nursing students. Eur Sci J 2016;12(15).

19. Stephan F, Groetschel H, Büscher AK, Serdar D, Groes KA, Büscher R. Teaching paediatric basic life support in medical schools using peer teaching or video demonstration: a prospective randomised trial. J Paediatr Child Health 2018;54(9):981-6.

20. Kim JY, Ahn HY. The effects of the 5-step method for infant cardiopulmonary resuscitation training on nursing students' knowledge, attitude, and performance ability. Child Health Nurs Res 2019;25(1):17-27.

21. Nourkami-Tutdibi N, Hilleke AB, Zemlin M, Wagenpfeil G, Tutdibi E. Novel modified Peyton's approach for knowledge retention on newborn life support training in medical students. Acta Paediatr 2020;109(8):1570-9.

22. Meaney PA, Topjian AA, Chandler HK, Botha M, Soar J, Berg RA, et al. Resuscitation training in developing countries: a systematic review. Resuscitation 2010;81(11):1462-72. 